\title{
Classroom Teaching Construction for College Ideological and Political Theory Based on Study of Teacher-Student Interaction Learning
}

\author{
Jiani Li \\ Hunan International Business Vocational College, Changsha, Hunan, 410201, China
}

Keywords: Teacher-student interaction, Ideological and Political Theory, Classroom teaching

\begin{abstract}
College Ideological and Political Theory teaching owns unique teaching content and personalized teaching method, and can generate corresponding positive influence on students' growth of ideological awareness through teaching practice. As new course reform is implemented, corresponding changes have taken place to the teaching objective and teaching evaluation of college Ideological and Political Theory in recent years. The leading position of students in teaching is more valued. It is hoped that positive effect is generated on classroom teaching effect through constructing harmonious and interactive teacher-student relationship. In combination of basic teaching conditions of college Ideological and Political Theory, this paper proposes measures to teach Ideological and Political Theory based on teacher-student interaction learning and hopes to offer corresponding guidance for college Ideological and Political Theory teaching.
\end{abstract}

\section{Introduction}

In recent years, college Ideological and Political Theory teaching has been faced with larger challenges under the background of new media intervention and information explosion. College Ideological and Political Theory classroom as an important base for implementing ideological and political education for college students and guiding students to practice Marxist ideology generates positive influence on students' world outlook, outlook on life and values. Thus, it is required to enhance attention to Ideological and Political Theory teaching. In combination of teaching status of college Ideological and Political Theory, this paper puts forward corresponding suggestions on teacher-student interaction teaching mode and analyzes specific application of it in classroom teaching, in the hope of offering certain support and reference for teaching reform.

\section{Basic conditions and features of college Ideological and Political Theory teaching in China}

Guiding ideology of college Ideological and Political Theory teaching in China. At present, teaching framework used in college Ideological and Political Theory teaching in China is mainly based on "two-course" course setting provisions formulated by Ministry of Education at the end of the last century and relevant guiding opinions. In 2005, the course gained corresponding development and perfection during education policy adjustment. After preliminary perfection, college Ideological and Political Theory teaching is fully exerted in ideological education of college students, and the teaching method is also improved. Thus, a diversified development trend gradually forms in ideological and political education field. "Multi-dimensional teaching perspective, student-centered teaching and subject combination” become new features of ideological and political education ${ }^{[1]}$.

Main content of college Ideological and Political Theory teaching. College Ideological and Political Theory teaching mainly regards Marxism-Leninism, Mao Zedong thought, Deng Xiaoping Theory and three-representative theory as the guiding ideology, and the course construction is mainly based on individualized moral education objective of different colleges ${ }^{[2]}$. The basic teaching content includes Basic Principle of Marxism, Introduction to Mao Zedong Thought, Outline of Chinese Modern History, Situation and Policy etc. Since Ideological and Political Theory teaching owns strong profoundness in theory, and the concept is abstract. Thus, the teaching mode of purely infusing relevant concepts, views and principles in teaching may form every easily. This will exert poor influence on students' learning initiative and seriously restricts exertion of expected teaching effect. 
Basic objective and evaluation of college Ideological and Political Theory teaching. Traditional evaluation criterion of college Ideological and Political Theory teaching is mainly set by focusing on teaching objective and implemented by basic teaching methods and main teaching contents. For objective assessment, knowledge should serve as the assessment center to check students' knowledge mastery, delivery, application and re-presentation. Teaching method assessment should adopt quantitative assessment as the main means to check completion situation of teaching objective in teaching process, but the process of completing teaching objective is ignored ${ }^{[3]}$. Teaching content assessment requires comprehensiveness and systematicness. In particular, students' knowledge mastery situation should be checked. Seeing from implementation of examination and evaluation standards, teaching evaluation mode based on knowledge instruction in China's traditional teaching can neither effectively mobilize students' learning initiative nor truly and objectively reflect students' learning situations. Thus, it has certain limitation and needs to be properly innovated and adjusted in combination of more scientific examination and assessment method in order to boost assessment performance.

College Ideological and Political Theory teaching activity should be a teaching-learning interaction process. In teaching practice, teachers should not merely complete their teaching plans, but also help students internalize what they learn, transform what they learn to personalized views and then form their own world outlook and methodology through proper teaching guidance. To adapt the change of Ideological and Political Theory teaching from original knowledge infusion mode to practical application mode in the new period, teachers should combine actual teaching demand to construct a teaching evaluation system which adapts to current teaching reform, to stimulate students' learning initiative and to promote teachers' reflection on teacher-student interaction teaching relation through re-confirming teaching evaluation standard and to improve scientificity and rationality of teaching evaluation through interaction teaching.

\section{College Ideological and Political Theory teaching mode construction based on teacher-student interaction}

It can be seen from the above analysis that, for college Ideological and Political Theory teaching, high-quality teaching activity needs joint participation of teachers and students. So in current stage, college Ideological and Political Theory teachers should actively alter traditional teaching concept, regard students as the center of teaching activity and mobilize students' learning initiative so as to enhance teaching effect and provide certain support of intensifying ideological and political accomplishment of college students.

In essence, teacher-student interaction teaching mode regards students as the subjects of teaching activity and deems students' learning quality as the teaching objective; the teaching effect is intensified through teacher-student interactions and student-student interactions, and then students are guided to construct theme structure of classroom teaching through independently inquiry and cooperative learning ${ }^{[4]}$. Teacher-student interaction teaching mode is a creative teaching mode which is proposed by modern education field through continuous study and analysis. Such mode can trigger resonance of teachers and students and reach the optimal teaching effect through rationally regulating teacher-student relation and student-student relation and creating sincere, harmonious and multi-interactive learning atmosphere.

Teacher-centered interaction teaching mode of Ideological and Political Theory. Firstly, theoretically, teacher-centered teaching mode can enlighten students' learning, gradually cultivate students' self-judgment ability through guiding teaching, disclosing truth and correcting students' ideology and facilitate their integrated development. Teacher-centered teaching mode mainly means teachers overall and systematically display basic content of Ideological and Political Theory course, and guide students to accomplish cognition and understanding of basic knowledge points during participating in classroom teaching activities so as to lay a solid foundation for cultivating their political accomplishment. Secondly, from the perspective of specific realization approach, content characteristics of Ideological and Political Theory are analyzed. For the knowledge points with strong theoretical property and abstraction property such as human nature and era background of personality 
training, students are difficult to these, so teachers need to combine students' law of cognition and growth law to rationally select teaching content, service for improving students' learning effect and practically intensity actual teaching quality of Ideological and Political Theory ${ }^{[5]}$.

Student-centered interaction teaching mode of Ideological and Political Theory. The study on student-centered interaction teaching mode of Ideological and Political Theory is still analyzed from both theory and practice. Firstly, according to theoretical basis, constructivism learning ideology gradually rose in American and European countries in 1990s. Constructivism learning ideology stresses to deem students as the center of teaching activities and to stimulate students' enthusiasm and initiative in learning process, and highlights teaching situation, construction and corresponding sociality. Thus, it is an advanced teaching theory ${ }^{[6]}$. The application of such education thought in college Ideological and Political Theory can fully mobilize students' learning initiative, dig their potential, stimulate their pioneering spirit and boost teaching effect through effective cooperation between the teacher and students. Meanwhile, college Ideological and Political Theory not just owns strong abstraction property, but its practicalness should be valued. Under interaction teaching mode, students can internalize what they learn, change their ideas through practical application and generate certain positive influence on future development. Simply speaking, student-centered teaching mode means some student-oriented teaching activities are rationally carried out in accordance with teaching content and students' learning demand. Secondly, from the practical perspective, for the teaching content closely related to students' actual life, teachers should give full play to students' subjectivity function in classroom teaching through scientific teaching design, highlight students' ability to learn, think and handle problems and then actively cultivate studnets' spirit of bold query and independent inquiry under the functions of teacher-student and student-student interaction teaching. Such teaching mode also actively influences the improvement of teaching level ${ }^{[7]}$.

Teacher-student-centered interaction teaching mode of Ideological and Political Theory. At theoretical level, teacher-student-centered interaction teaching mode of Ideological and Political Theory mainly means an interactional internal relation exists between studnets and teachers and among studnets in Ideological and Political Theory teaching, which makes both teachers and studnets learn in teaching practice and seek common progress and development in practical teaching. Meanwhile, to make teachers and students as the center of interaction teaching mode, teachers are required to actively accept studnets' new ideas, absorb wisdom of the public, know their shortcomings and gradually improve. In other words, under the influence of teacher-student interaction teaching mode, both the teacher and studnets should improve in learning process and gain all-round development through interactions except basic teacher's "teaching” and studnets' "study". Seeing from realization approach of teacher-student-centered interaction teaching mode of Ideological and Political Theory, some teaching contents can be jointly prepared by the teacher and studnets. Even studnets may give explanations to deepen their understanding, motivate their learning interest and obtain good teaching effect ${ }^{[8]}$. At the same time, in terms of teaching practice, college teachers may properly use computer multimedia technology to analyze and organize the hot issues, select teaching content and method, and provide correct ideological guidance. In this process, teachers may fully utilize interactivity feature of internet teaching and multimedia teaching to enhance connections among studnets, guide and help studnets to form correct ideology.

\section{Specific application of teacher-student interaction teaching in college Ideological and Political Theory teaching}

For Ideological and Political Theory teaching, all above teaching mode inevitably comes from classroom teaching practice, and represents the summary and improvement of teachers' rich teaching experience, so they own certain advancement and gain better development in future application. When teachers choose and construct rational teaching mode, they should correctly handle the relationship between tradition and innovation in teaching method reform, and choose the most suitable teaching mode in combination of actual situations. For teacher-student interaction teaching mode, teachers should exert two important functions in teaching activities. On the one hand, teachers should urge and supervise interactions between all participants and teaching activities through proper 
guidance; on the other hand, teachers should keep certain independence in teaching practice, and influence students through teachers' behaviors. The role of teachers in teaching activity is diversified. They are guides and assistants of class teaching activities. They not just overall guide students' study, but also observe students' classroom performance and then evaluate students' learning effect ${ }^{[9]}$. Similarly, in interaction teaching, the role of students is also diversified. They are activity participants, acceptors and communicators of ideological and political knowledge as well as national political thought. Hence, compared with traditional teaching mode, teacher-student interaction teaching can let students give play to different functions and generate certain influence on teaching quality improvement and students' all-round development.

\section{Conclusion}

In one word, the application of teacher-student interaction teaching mode can change teachers' teaching view, manifest human nature features of Ideological and Political Theory education, give play to students' role of subjects, promote them to really participate in teaching practice, improve teaching effect and lay a solid foundation for future development.

\section{References}

[1] Li Liang, Teacher-Student Interaction Teaching Mode Construction Based on Problem Logic under Network Environment. China Educational Technology, 2011(12):94-97.

[2] Wang Danping, Study on Teacher-Student Interaction in College Ideological and Political Theory Teaching. Intelligence, 2013(12):142-142.

[3] Lu Guojie, Enhancement of Teacher-Student Interaction Mechanism in Ideological and Political Theory Teaching. Overseas Travel and Employment, 2010(17):129-130.

[4] Zhang Jing, On Teacher-Student Interaction Effectiveness in College Ideological and Political Theory Teaching. Education and Vocation, 2014(5):141-142.

[5] Zheng Zhongping, On Enhancement of Teacher-Student Interaction Effectiveness in College Ideological and Political Theory Teaching. Continue Education Research, 2013(6):110-111.

[6] Tu Dandan, Study on Teacher-Student Interaction Mode of College Ideological and Political Theory under Network Environment. Forward Position, 2013(18):193-194.

[7] Huang Sheng, Huang Peng, Exploration of Teacher-Student Interaction Teaching Mode of Ideological and Political Theory - Case Study of Ocean University of China. High School Years, 2013(13):175-176.

[8] Geng Jiajin, On Teacher-Student Interaction of College Ideological and Political Theory and Enhancement Strategy. Education and Vocation, 2013(21):151-152.

[9] Xu Yuenan, Wu Xiaolong, Hua Qihe et al., Exploration of Teacher-Student Interaction in Teaching Ideological and Moral Cultivation and Basic Law Education [J]. Journal of East China Institute of Technology (Social Science Edition), 2013,32(1):94-96. 